\title{
A PERSONALIZAÇÃO DO EMBRIÃO HUMANO: DA TRANSCENDÊNCIA NA BIOLOGIA
}

Naara Luna

É nos conceitos biológicos que residem os últimos vestígios de transcendência de que dispõe o pensamento moderno (Lévi-Strauss 1982:52).

Este artigo examina representações de embrião e feto humanos presentes em duas fontes: no discurso de profissionais envolvidos com a medicina de reprodução humana e os serviços de infertilidade e em textos publicados na grande imprensa. Apreendeu-se o discurso desses profissionais durante pesquisa de campo para o doutorado em antropologia. As entrevistas ocorreram entre os anos de 2000 e 2002, com profissionais de serviços públicos de reprodução assistida em São Paulo, e de um serviço universitário de infertilidade no Rio de Janeiro. Citam-se diretamente apenas seis das entrevistas. O trabalho de campo incluiu o comparecimento a eventos da área e o registro de material televisivo.

Selecionaram-se textos publicados na imprensa a partir de levantamento sistemático no jornal O Globo entre 2000 e 2005. A prioridade foram textos da página de opinião, em que os autores, em sua maioria, não são profissionais do jornal, mas integram alguma categoria social que lhes confere autoridade para se pronunciarem sobre o assunto. Incluiu-se número menor de matérias propriamente jornalísticas deste e de outros veículos da imprensa. ${ }^{1}$ A fim de investigar as representações sobre o embrião humano, o enfoque foi em textos que lidavam com o uso de embriões humanos como material de pesquisa, em particular para formar células-tronco. O período do levantamento antecede e ultrapassa um ciclo de eventos no Poder Legislativo referente à aprovação da nova Lei de Biossegurança, cujo anteprojeto foi encaminhado pelo Executivo ao Congresso em 31 de outubro de 2003, com tramitação até 24 de março de 2005, além de uma ação de inconstitucionalidade em maio do mesmo ano (cf. Cesarino 2006). A nova Lei de Biossegurança permite, 
para fins de pesquisa e terapia, a utilização de células-tronco embrionárias obtidas de embriões produzidos por fertilização in vitro e não transferidos para o útero, desde que os embriões sejam inviáveis ou estejam congelados há três anos ou mais. Exige-se o consentimento dos "genitores" (os fornecedores de gametas) para tanto.

O debate sobre o uso de embriões humanos em pesquisa indica situações de "drama social" (Turner 1957) — conceito para situações de crise que emergem periodicamente e revelam contradições escondidas e conflitos em um sistema social. Conflitos representam um desafio a alguma norma. No drama social, conflitos de interesses latentes manifestam-se, o que ocorre em qualquer nível da organização social, e se desenrolam até o desfecho em comportamento convencional atuado publicamente. A resolução jurídica com autorização das pesquisas e o fim das manifestações públicas de protesto representariam o desfecho. ${ }^{2}$ Esses debates sob análise constituem controvérsias sociais: polêmicas em que intervém uma série de agentes sociais. Trata-se de um momento de expressão e redefinição de pontos e problemas importantes na constituição de uma sociedade (Giumbelli 2002). Mesmo os profissionais de reprodução assistida respondem com ciência de se posicionarem em debate politizado sobre a condição do embrião humano manipulado em laboratório.

Nos depoimentos dos entrevistados e nos textos da imprensa há representações sobre o embrião e o feto humano que lhe atribuem ou negam a condição de pessoa. A argumentação baseia-se majoritariamente em descrições de caráter biológico. A interpretação dessas descrições é pautada por valores correntes da cosmologia ocidental moderna, como a oposição das províncias ontológicas Natureza e Cultura, constituinte dessa cosmologia. As representações biologizantes relacionam-se à mudança de episteme ocorrida no Iluminismo, considerando real o mundo físico, enquanto os sentidos culturais seriam epifenômenos (Laqueur 1992:6-7). A biologia - o corpo estável, a-histórico e sexuado - é fundamento epistêmico para questões da ordem social. A partir de tal perspectiva examinam-se as representações do embrião encontradas nos discursos.

\section{O contexto do debate: as técnicas}

Técnicas de reprodução assistida são procedimentos da medicina de reprodução humana que substituem o ato sexual na concepção (Corrêa 2001). A fertilização in vitro (FIV) é a técnica que produz embriões em laboratório. A fim de aumentar a eficácia da técnica proporcionando maiores chances 
de gravidez, estimula-se a maturação de vários folículos no ovário, formando óvulos que serão coletados e unidos a sêmen tratado. Freqüentemente criam-se embriões além do número que seria seguro transferir para o útero (quatro). Os embriões restantes podem ser criopreservados (congelados) em cilindros de nitrogênio, guardando-os para nova tentativa, se não ocorrer gravidez. Nem sempre os geradores dos embriões retornam para transferir os criopreservados.

Não há legislação para reprodução assistida no Brasil e vários projetos tramitam no Congresso Nacional (Diniz 2003). Os projetos referem-se à legislação do aborto, preocupando-se com a proteção do embrião. Um projeto proíbe o congelamento, e todos discutem o número máximo de embriões a transferir, em função da impossibilidade legal da redução embrionária (Diniz 2003). ${ }^{3}$ A regulamentação vigente, Resolução 1358/92 do Conselho Federal de Medicina (CFM), proíbe destruir embriões, mas faculta a doação para outros casais. A mudança veio com a nova Lei de Biossegurança, conforme visto acima, que autorizou a produção de células-tronco para pesquisa e terapia a partir de embriões inviáveis ou congelados há três anos ou mais por ocasião e a partir da aprovação da lei, procedimento condicionado ao consentimento dos "genitores" (Cesarino 2006).

O destino desses embriões entrou no debate público pelo ângulo relacionado com a medicina regenerativa. Essa nova especialidade propõe a terapia com células-tronco para reparo ou substituição de tecidos que sofreram lesão ou degeneração (Borojevic 2004). O uso de células-tronco permitiria recriar tecidos e repetir sua geração. Célula-tronco é a "célula com capacidade de auto-renovação limitada/prolongada, capaz de produzir pelo menos um tipo de célula altamente diferenciada" (Pereira 2002:65). Células-tronco adultas têm capacidade limitada de diferenciação: as contidas na medula óssea e no sangue do cordão umbilical são aplicadas em diversas terapias. As células-tronco embrionárias constituem o embrião em seus primeiros dias. Até o terceiro dia, o embrião está no estágio de mórula: uma massa de oito células (blastômeros) totipotentes: cada uma pode originar outro embrião idêntico, com potencial de gerar um organismo completo. No quinto dia, ocorre o estágio de blastocisto: composto de um nó embrionário que dará origem ao corpo do embrião, contendo células com potencial de gerar qualquer tecido do corpo, exceto os anexos embrionários (cordão umbilical, placenta, bolsa amniótica).

Sugere-se o uso dessas células pluripotentes na medicina regenerativa, o que implicaria destruição dos embriões e a necessidade de muita pesquisa para controlar a diferenciação celular. Em função do potencial terapêutico de longo prazo após pesquisas futuras, propõe-se usar embriões "abandonados 
pelos pais" (sic) (cf. Luna 2001b) para pesquisa e produção dessas células. Esse procedimento é designado na imprensa de "clonagem terapêutica": transferência do núcleo de célula (exceto gametas) de um paciente para as células embrionárias enucleadas (de núcleo extraído) e seu posterior cultivo para produzir tecidos compatíveis geneticamente com o receptor. Há debate entre quem considera o embrião humano pessoa, sujeito de direitos e quem o considera material celular.

\section{O estatuto do embrião: a nova figura de pessoa}

O ensaio de Mauss (1974), Uma categoria do espírito humano: a noção de pessoa, a noção do "eu", é o texto clássico na antropologia para a discussão da categoria de pessoa. Mauss aborda a história social das categorias do espírito humano e considera a noção do self (a personalidade consciente) um fenômeno universal. Várias sociedades alcançaram a concepção de personagem, o papel em dramas sagrados e na vida familiar. A idéia ocidental de persona, oriunda da máscara ritual e de antepassados, surge no início da civilização latina. O conceito de pessoa humana como entidade completa, dependente só de Deus, formou-se em Roma, constituindo fato fundamental do Direito. Em contraste com o cidadão, o escravo não tem personalidade: não tem o próprio corpo, antepassados, nome nem bens. Na filosofia estóica, acrescenta-se ao sentido jurídico de pessoa o sentido moral de ser consciente, autônomo, livre e responsável. A consciência de si vira atributo da pessoa moral. Com base na unidade das pessoas na Trindade, criou-se a idéia de pessoa como substância racional, indivisível e individual. Os movimentos sectários da Reforma Protestante colocaram questões da liberdade individual, da consciência individual e da comunicação direta com Deus. A noção de pessoa torna-se a categoria do eu no final do século XVIII. Na filosofia, Fichte faz dela a condição da consciência e da ciência, da razão pura. A partir dessa nova categoria do eu, realiza-se a revolução das mentalidades das declarações de direitos (Mauss 1974). A definição da condição de pessoa e de seus direitos é central no debate sobre o estatuto do embrião humano.

La Fontaine (1985), recuperando o debate antropológico sobre o tema, faz a seguinte distinção: o ser humano como organismo biológico é um "indivíduo", o indivíduo empírico (cf. Dumont 1997); o self seria a consciência de si como identidade; e "Pessoa" constitui um complexo de relações sociais, termo técnico que abstrai características e papéis nas relações sociais da realidade empírica. O conceito de pessoa relaciona-se ao problema da relação 
entre indivíduo (empírico) e sociedade, comum a todas as sociedades (La Fontaine 1985:125). Ingold formula a relação entre indivíduo e sociedade, constitutiva da noção de pessoa: todo ser humano vem ao mundo situado em um campo de relações sociais; tornar-se pessoa é questão de reunir essas relações em estruturas da consciência (1990:221).

Dumont $(1992,1997)$ analisa a formação do indivíduo, categoria de pessoa peculiar ao Ocidente moderno. Não se refere ao agente empírico, o ser humano individual, mas ao "ser de razão, o sujeito normativo das instituições" (1997:57), "o ser moral independente e autônomo, [...] essencialmente não social, que veicula nossos valores supremos" (1992:35). O autor traça a emergência histórica do ideal individualista na sociedade moderna, com a polarização indivíduo e sociedade, e parte do pressuposto que a sociedade preexiste ao indivíduo (1992). Há dois sentidos para indivíduo: o agente empírico, presente em qualquer sociedade, e o sujeito moral dos valores centrais de igualdade e de liberdade, acepção central na ideologia das sociedades modernas (1997). Nas sociedades tradicionais, a medida de valor é o ser humano coletivo, a sociedade; já nas sociedades modernas, prevalece o ser humano elementar e o indivíduo encarna toda a humanidade. Nas sociedades modernas, há antagonismo entre indivíduo e sociedade, esta última representada como resíduo não-humano que cerceia a realidade última psicológica e moral contida no indivíduo (Dumont 1997).

Segundo Simmel (1971), a ênfase consciente em individualidade como princípio surgiu na Renascença: a distinção de ser único. No contexto do Iluminismo e da Revolução Francesa, buscava-se o individualismo baseado na noção de igualdade natural dos indivíduos. Essa concepção origina-se do conceito de natureza do século XVIII de orientação mecanicista e científica: a lei geral. Nesse conceito de individualidade, despindo-se o ser humano de tudo o que não é totalmente ele mesmo, o que resta é a substância do gênero humano que reside em todos. Segundo Kant (apud Simmel 1971), se o ser humano é profano, o gênero humano é sagrado. No novo individualismo, o indivíduo quer se distinguir dos demais, tornando-se insubstituível: a individualidade é primordial e eterna no ser humano. Trata-se do individualismo qualitativo do Romantismo, que se opõe ao individualismo numérico do Iluminismo (Simmel 1971).

Noções de pessoa e de indivíduo estão presentes em todas as sociedades em relação dialética, mas a noção de indivíduo como unidade isolada e autocontida desenvolveu-se mais no Ocidente, enquanto a de pessoa predomina em sociedades holísticas e tradicionais. A pessoa é a categoria relacional, presa à totalidade social e complementar aos outros, enquanto o indivíduo é uma categoria de pessoa livre, sem mediação com o todo 
(DaMatta 1997). A noção ocidental de pessoa não se reduz ao indivíduo. Segundo Strathern (1999:95), no contexto do parentesco ocidental pode-se pensar a noção de pessoa como ente individual e como ente emaranhado em relacionamentos sociais.

No tocante às novas tecnologias reprodutivas, surge um novo ente legal e social: o embrião extracorporal criado por fertilização in vitro (Strathern 1992). A análise de Strathern sobre os debates, os valores implicados e o contexto cultural que cerca a elaboração da legislação britânica sobre reprodução assistida virou referência clássica na antropologia. Também Salem (1997) aprofundou-se nas implicações que envolvem o estatuto do embrião e a noção de pessoa. Ambas as autoras fundamentam-se principalmente em material de especialistas eruditos: o relatório Warnock, que traça diretrizes para a legislação britânica concernente às técnicas de reprodução assistida quanto às relações de parentesco e ao estatuto do embrião humano extracorporal, e os artigos acadêmicos da área de ética, o debate legislativo e as leis sobre o estatuto do embrião (gravidez, aborto e reprodução assistida).

Strathern (1992) analisa o embrião extracorporal no tocante a valores e a configurações do parentesco ocidental, revelando a ambigüidade de sua posição entre indivíduo isolado e participante da rede de parentesco. Salem (1997:77) examina o estatuto moral do embrião e conclui: na formulação do dilema referente à manipulação de embriões estão sendo discutidos a Pessoa, seu significado e atributos. Com base em material etnográfico e textos de opinião, continuo por outra perspectiva os questionamentos iniciados pelas autoras. Para ambas, a discussão segue a linha da oposição entre indivíduo e pessoa, demonstrando que a definição do embrião como pessoa revela o indivíduo, categoria de pessoa ocidental.

Este artigo examina como se atribui ou se nega a condição de pessoa humana, ou de ser humano, ao embrião. O foco é analisar a argumentação acerca da condição conferida ao embrião humano fora do corpo e criado em laboratório. Antes de perguntar quando o embrião corresponde à pessoa e quando, ao indivíduo, o material coligido leva a indagar sobre a distinção entre o embrião "pessoa" ou "ser humano" e o ente ou material biológico desprovido da atribuição desse estatuto. No material apurado, a questão para os informantes está em definir se o embrião extracorporal é um ser humano ou se é material biológico, sendo lícito seu uso em pesquisas. Se o problema para os informantes é definir se o embrião é ou não pessoa, que tipo de representações veiculam e como fundamentam sua argumentação?

Trabalho etnográfico evidenciou que profissionais de reprodução humana entrevistados, ao justificarem sua opinião sobre o estatuto do embrião, usam mais argumentos biologizantes do que argumentos de outra ordem 
(Luna 2004). Tanto para comprovar que o embrião era "uma vida", como para negar, a argumentação valeu-se de dados biológicos. Referências a conceitos religiosos (presença de alma) e ao direito (cidadania) foram mais evocadas para negar o estatuto de pessoa: "não tem alma", "não é cidadão". Certas opiniões sobre o embrião escaparam à argumentação biologizante: uma definição de caráter filosófico como pré-homem ou pré-humano (ver adiante), a defesa explícita da posição religiosa: "no nosso conceito de religião, é vida", e definições sociais: "é uma criança", "já é pessoa". ${ }^{4}$

O artigo analisa esse processo de biologização da pessoa, inspirado na observação de Schneider (1968) sobre a simbólica do parentesco nos Estados Unidos: a verdade científica é incorporada ao saber nativo sobre o parentesco. Os conceitos biológicos definidores do estatuto do embrião humano podem ser incorporados ao saber sobre parentesco, constituindo assim o processo de biologização. ${ }^{5} \mathrm{Na}$ presente abordagem, a noção de pessoa é englobante, representando o sujeito, o ser humano, enquanto o conceito de indivíduo é tratado como categoria de pessoa. Há representações mais relacionais em que o embrião seria caracterizado como pessoa, e representações de isolamento e autonomia em que o embrião surge como indivíduo.

Simmel, discorrendo sobre cultura subjetiva, afirma que a natureza é fase específica do desenvolvimento em que o sujeito embrulha (enfolds) seu próprio potencial ${ }_{1}^{6}$ e que termina quando uma vontade mais inteligente e dotada de propósitos toma essas forças e leva o sujeito a uma condição que ele não poderia alcançar por si mesmo. O cultivo de si implica a existência de um estado natural anterior não cultivado, de modo que a transformação está latente no potencial estrutural da natureza desse sujeito (Simmel 1971:228). Essa noção de potencialidade constitui ponto-chave do debate sobre a condição do embrião. Ao considerar a necessidade de recontextualizar o embrião humano (Novaes e Salem 1995), examino a argumentação que cerca a atribuição ou a negação da condição de pessoa ao embrião humano no quadro da gestação, no debate sobre o aborto e no contexto de laboratório.

Segundo Franklin (1991), os grupos antiaborto na Inglaterra afastaram-se da retórica de considerar a vida humana sagrada porque criada por Deus, substituindo definições religiosas da vida por definições biológicas. A condição de pessoa do feto não está mais na posse da alma, mas na posse de corpo e de genótipo humanos. O feto aparece como agente individual separado da mãe. Tecnologias visuais (câmeras no útero, ultra-sonografia) constroem a imagem do feto separado, definindo-se sua condição de pessoa de modo a-social, a partir de "fatos naturais". A construção do feto como pessoa potencial e individual vale-se de raciocínio teleológico, e está baseada em conceitos de força vital biológica e de determinismo genético: 
no momento da concepção, seu curso de vida estaria mapeado geneticamente. A individualidade do feto mostra-se no conceito de viabilidade, sua capacidade de nascer vivo com existência independente da mãe (Fyfe 1991), e na distinção entre embrião e pré-embrião. A biologia transforma-se em base para a construção cultural de categorias sociais (Franklin 1991).

Leal e Lewgoy (1995) verificaram ontologias distintas referentes à condição de pessoa do embrião humano no debate sobre o aborto. Há uma ontologia substancialista que baseia a proteção do embrião no critério biológico de presença da pessoa humana desde a concepção. Na antiga versão religiosa dessa ontologia, a alma passa a existir a partir daí. Uma versão laica dessa ontologia substancialista identifica o estatuto jurídico de pessoa humana no esboço genético do indivíduo contido no genoma. Há uma ontologia relacional em que a garantia de direitos a seres humanos incompletos depende do arbítrio da comunidade, faltando ao embrião o atributo da racionalidade.

Uma variação desta ontologia relacional está na reflexão de Maguire: o estatuto de pessoa do embrião começa quando a "mãe faz aliança de amor com a vida em desenvolvimento dentro dela para levá-la ao nascimento" (apud Junker-Kenny 1998:63). Essa teóloga nega a imoralidade da eliminação dos "óvulos fecundados" ou a experimentação nesse material, pois "não há pessoas flutuando em tubos de ensaio". A socialidade seria aspecto fundamental da pessoa, e o lado biológico não basta para garantir o início de tal condição. Esta abordagem relacional coaduna-se com os achados de Leal e Lewgoy (1995) sobre práticas abortivas nas camadas populares brasileiras. O não-reconhecimento do atraso menstrual como gravidez (recusar a existência do embrião) é estratégia que abre espaço para usarem chás ou medicamentos abortivos. Existe também entre essas mulheres o princípio de condenação do aborto como pecado ou crime, tendo como base a versão religiosa católica dessa ontologia de pessoa.

No debate sobre o estatuto do embrião, encontram-se noções essencialistas da emergência da condição de pessoa, em que o episódio da concepção é o marco inicial, e noções gradualistas, em que o atributo de pessoa se instala ao longo do desenvolvimento. Segundo Strathern (1992:174), essas posições se baseariam em uma visão evolucionista do tempo, identificada com a posição gradualista, e uma visão episódica do tempo, representando um início radical, o que constituiria a visão essencialista. No Direito, Leite (1995) fala em teoria genético-desenvolvimentista e teoria concepcionista, defendendo a última interpretação.

Se o debate sobre a condição de pessoa do embrião origina-se de discussões sobre a licitude do aborto, as novas tecnologias reprodutivas levantam 
outros ângulos da questão, em função das possibilidades de intervenção em embriões criados em laboratório. O conceito de pré-embrião, designando a fase anterior ao surgimento da linha primitiva, abre espaço para experimentação com esses embriões até o décimo quarto dia após a fertilização, ${ }^{7}$ interesse da comunidade científica inglesa (Mulkay 1997). Um comitê interdisciplinar em fertilização e embriologia humanas, instituído pelo governo inglês em 1982, elaborou o Relatório Warnock a fim de criar parâmetros para políticas públicas e legislação inglesa sobre a reprodução assistida e a manipulação de embriões (Cannell 1990; Salem 1997). As recomendações do relatório são referência na discussão das tecnologias reprodutivas e do estatuto do embrião. Após publicado o relatório, a embriologista do comitê sugeriu o termo "pré-embrião" para designar essa fase inicial (Mulkay 1997).

Conklin e Morgan (1996) mostram a tendência nos Estados Unidos de buscar na biologia marcadores fixos estruturais da condição de pessoa. Salem (1997) analisa argumentos para atribuir ou negar o estatuto de pessoa ao embrião: o primeiro diz respeito à sensibilidade do embrião, sinal da emergência dos primórdios do sistema nervoso central com a placa neural por volta do $22^{\circ}$ dia. Este traço representa o primeiro indício da qualidade racional da espécie humana. Adota-se o $14^{\circ}$ dia para marco preferencial do estabelecimento da condição de pessoa porque assinala o término da implantação no útero, mas principalmente por indicar o fim do estágio indiferenciado do embrião, com formação da linha primitiva. A partir da emergência dessa estrutura, representa-se a individualização do embrião, na impossibilidade deste dividir-se ou fundir-se a outro. Outro argumento, oriundo da bioética, questiona a existência de identidade individual de um embrião antes do quinto dia, quando cada célula tem a capacidade de exprimir o programa genético de um indivíduo completo, sendo totipotente (Comitê Nacional de Bioética 1997).

Tanto os critérios da emergência da linha primitiva, como a composição inicial do embrião de células totipotentes, capazes de gerar mais de um indivíduo, revelam a ênfase no valor da individualidade para parâmetro da condição de pessoa. Mesmo nas posições gradualistas, que definem a condição de pessoa no desenvolvimento, estamos diante de marcos físicos. Segundo Salem (1997), esse tipo de definição evidencia a biologização da identidade, pois até mesmo critérios relacionais, como o vínculo entre mãe e embrião, são concebidos em termos biológicos: o processo de nidação. A atribuição da condição de pessoa ao embrião a partir de critérios biológicos desconecta e oculta relações sociais, em particular as de parentesco, representando-o como um ente desprovido delas. Um acirramento desse processo está na definição da identidade individual com base nos genes que corporificariam a verdade 
essencial: representa-se a pessoa como seu genoma. Nesse sentido, a Igreja Católica afirma o embrião como ser humano desde a fertilização, com base em "evidência [...] da moderna ciência genética", a ciência demonstrando que "desde o primeiro instante encontra-se fixado o programa daquilo que será este ser vivente" (Congregação para a Doutrina da Fé 1994:20). ${ }^{8}$

\section{O embrião como pessoa biológica}

A afirmação de palestrante médico sintetiza posições polarizadas quanto à condição do embrião: "o embrião é célula viva, e não uma vida". ${ }^{9}$ Nota-se a diferença de concepção entre expressões etimologicamente aparentadas: "vivo" (célula viva, ser vivo) e "vida" (uma vida, no sentido de uma pessoa).

Embora discursos distintos mencionem características de pessoa do embrião, a atribuição de condição humana não é unânime. Ciente da politização do debate sobre o estatuto do embrião humano, indagado sobre o que era o embrião criado fora do corpo, um médico rebateu: "Você quer saber se ele é cidadão? Se tem direito? [...] É um bolo de células que tem potencial de virar gente."10 Perguntado se fazia diferença estar no útero, respondeu: "É diferente, porque no útero ele está numa condição diferente [...] O embrião no vidro é embrião no vidro. No útero tem potencial maior. Embrião no útero você vai mexer menos." Esse médico define o estatuto do embrião de forma relacional. Seu potencial varia conforme o contexto. Não se trata de uma vida em termos absolutos, do indivíduo como valor sagrado. Faltam características ao embrião extracorporal para ser sujeito de direito: a indiferenciação do "bolo de células" não representa a figura humana, mas no útero fica aumentado o seu potencial.

Que tipo de relação legal se estabelece entre embriões criopreservados em clínicas e seus geradores, os fornecedores intencionais de gametas? O jornalístico Globo Repórter relatou o exemplo de um casal nos Estados Unidos que tinha 23 embriões congelados, após uma tentativa de fertilização in vitro com nascimento de gêmeos. O casal era contra aborto e doação de embriões para pesquisa. Não desejando mais filhos, selecionaram casais receptores pela Internet. ${ }^{11}$ No Brasil, o Conselho Federal de Medicina proíbe essa iniciativa, conforme a Resolução CFM 1358/92 que prescreve o anonimato na doação de gametas e de pré-embriões, prevendo responsabilidade da unidade de reprodução assistida na escolha de doadores. O programa explicava que embriões não eram pessoas segundo a lei americana, e sim objetos, fazendo-se um contrato de transferência de propriedade entre os pais doadores e os receptores. ${ }^{12}$ Nos Estados Unidos, nega-se a condição de pessoa ao embrião. 
Um dos profissionais aqui entrevistados, defensor da atribuição gradual do estatuto de pessoa, propôs conduta semelhante quanto aos embriões: "A melhor coisa para um embrião é o pai e a mãe, que estão geneticamente ligados a esse embrião, definirem o que ele tem que fazer". Seriam os "pais", isto é, os fornecedores intencionais de material genético, que deveriam definir o destino dos embriões: doação, pesquisa, congelamento, descarte. De modo semelhante, o discurso de funcionários dos serviços de fertilização in vitro, em particular onde há criopreservação, afirma que os embriões são da paciente, ou do casal (Luna 2004). Na comunicação "Criobiologia e fertilização assistida: problema ou solução", o Dr. Paulo Serafini esclareceu acerca do consentimento informado para criopreservação de embriões: "o paciente não é dono dos embriões, embora possa opinar sobre seu destino". ${ }^{13}$ Novaes e Salem (1995) demonstram que o embrião está em rede hierarquizada composta por diversos atores que o disputam e, conforme o contexto, não são os "genitores" (fornecedores de material germinativo) que mandam, mas as decisões ficam a critério dos profissionais e das instituições médicas, ou são arbitradas judicialmente.

Na legislação americana, na qual há forte tradição de direitos do indivíduo e do contrato, as relações de pertencimento entre os fornecedores intencionais de material genético e seus embriões transformam-se em relações de propriedade. ${ }^{14}$ Este tipo de relações entre indivíduos livres são pontos de articulação do comércio de material reprodutivo, prática criticada em países como a Inglaterra (Hirsch 1999), repercutindo na imprensa brasileira (Luna 2002a). O profissional que propôs que os "pais" fossem responsáveis por definir o destino dos embriões justifica a falta de condição de "indivíduo" do embrião, alternando argumentos de base biológica e social:

Ele não é indivíduo, não tem $\mathrm{RG}$, não tem $\mathrm{CIC}$, não tem absolutamente nada a não ser células [...] A gravidez anembrionada foi um pré-embrião e onde estava o embrião? Qual o direito daquela gravidez anembrionada? Ou você acredita que a gravidez anembrionada merece CIC e RG, se não tem batimento cardíaco nem embrião? [...] É um potencial indivíduo. Ele tem que ser tratado como um potencial indivíduo com todos os respeitos que um potencial indivíduo devia ter.

Embora a menção aos documentos CIC (cartão de identificação do contribuinte) e RG (o registro geral, documento de identidade) seja irônica, a atribuição da condição de pessoa na esfera legal passaria por procedimentos jurídicos, estabelecimento de registros e documentação. ${ }^{15}$ Ao se perscrutar o argumento da gravidez anembrionada, constata-se que biologicamente é possível o início de uma gestação em que células embrionárias ou o pré-embrião 
dêem origem a estruturas externas, como o saco gestacional, sem que haja a estrutura interna com o embrião propriamente dito, o nó embrionário com o batimento cardíaco. Ele afirmou provar cientificamente que "não quer dizer que [se] você juntou duas células, você vá ter um ser humano". A atribuição da condição de pessoa requer sinais distintivos de individualidade (Salem 1997), como o batimento cardíaco em uma estrutura que seja discernível do saco gestacional, aspectos citados pelo informante, o que consistiria em outros marcos físicos da emergência desse estatuto (Conklin \& Morgan 1996).

Com o objetivo de provar que o embrião não é ser humano, este mesmo entrevistado evoca o aspecto social da morte: "Um pré-embrião não é um ser humano, porque se fosse, nós teríamos que lamentar toda vez que nós transferíssemos embriões e essa paciente não engravidasse. Teríamos que fazer enterro simbólico dos pré-embriões formados em laboratório". O médico ironiza com a possibilidade de enterro simbólico de pré-embriões, visto que apenas pessoas mereceriam a cerimônia fúnebre. Nesta ironia, a definição social de pessoa morta com necessidade de realização de enterro precederia a definição biológica de pessoa.

No depoimento de outro profissional, percebe-se tensão entre o campo da medicina de reprodução humana (segmento da biomedicina) e o campo do Direito, o que representa uma luta por classificações para impor a definição legítima de aspectos do mundo social (Bourdieu 1996): a definição do embrião e de sua condição no mundo. Outro médico indagado responde sobre o momento em que se deve chamar de embrião:

É quando está implantado e forma o embrião que vejo no ultra-som. Aquilo é embrião, biologicamente. Antes disso eu já tinha discutido com um advogado a respeito, porque os advogados resolveram que o nome daquilo é embrião [...] O que um advogado conhece de biologia para definir que uma célula que foi fertilizada é um embrião, [o qual] é definido biologicamente como uma coisa que vai gerar um indivíduo e que tem as partes que geram um indivíduo? É o embrião do indivíduo, logo, é um esboço do indivíduo. Essas células, nessa fase, têm esse esboço do indivíduo? De maneira nenhuma. Têm na hora que está no ultra-som com cinco ou seis semanas, [quando] você vê o nó embrionário com batimento cardíaco, esboço de mãozinha, esboço de perninha, crânio. Aquilo lá é, mas aquilo veio do pré-embrião, assim como a membrana, a placenta, o cordão umbilical — tudo veio daquele embrião (Médico, grifos meus).

Fica explícita a disputa de classificações para impor a "definição legítima" do embrião e de sua condição de pessoa, com o médico afirmando a prioridade da biologia. Se coube historicamente aos saberes anteriores à 
biologia o estudo da concepção e a descrição instauradora de realidades como o embrião (Correia 1997), na esfera do Direito discute-se a personalidade civil. Conforme se depreende do estudo de Laqueur (1992), a descrição científica é tributária dos valores da sociedade circundante e moldada por eles. Não fosse assim, haveria consenso sobre certos aspectos físicos do embrião para defini-lo como pessoa.

Se voltarmos ao depoimento anterior, veremos que a descrição do embrião como pessoa tem por primeiro aspecto a implantação no útero, uma representação relacional. O segundo aspecto é a visualização mediada tecnologicamente pela aparelhagem de ultra-sonografia. Em terceiro lugar, está a definição de "embrião de um indivíduo". Note bem o uso do termo indivíduo e não pessoa. O "embrião de um indivíduo" é "esboço de indivíduo" e deve conter "partes que geram o indivíduo". Na palavra "esboço" está presente o argumento da potencialidade do embrião. As "partes" vêm enumeradas: "nó embrionário com batimento cardíaco, esboço de mãozinha, esboço de perninha, crânio". Trata-se das partes básicas da figura humana: coração, membros, cabeça.

O batimento cardíaco é referência-chave para o reconhecimento clínico da gestação. A representação dos dois últimos médicos, enfatizando o batimento cardíaco para reconhecer a individualidade do embrião, sua condição de pessoa, está em continuidade com a definição clínica do estabelecimento da gestação (Luna 2004). O médico, por fim, contrasta esse esboço de figura individual com a indiferenciação do "pré-embrião": "Essas células, nessa fase, têm esse esboço do indivíduo?" Ao responder negativamente à pergunta retórica, conclui que no "pré-embrião" não há esboço de pessoa humana, porque dali vieram tanto partes que compõem o embrião, como anexos da vida fetal: "a membrana, a placenta, o cordão umbilical":

Até ali, eu tenho um pré-embrião, que erradamente é chamado de embrião e se vulgarizou esse nome embrião para aquele grupo de células naquele estágio. Na verdade, aquele é um grupo de células que tem uma chance de 20 a 30\% para produzir placenta, cordão umbilical, membrana e talvez um embrião também.

Representa-se como característica das células do pré-embrião a potencialidade e não a individualidade, pois o "indivíduo" embrião talvez não surja daquele "grupo de células" que gerarão a placenta, o cordão umbilical, a membrana - estruturas essenciais para o desenvolvimento fetal, mas que pouco significam para a representação de pessoa na cultura ocidental. As idéias ocidentais de individualidade baseiam-se na separação física (Strathern 1992). Tais anexos, como cordão umbilical e placenta, são partes que, além de destacáveis da pessoa nascida, fazem a conexão com o útero 
materno que contém o embrião, provável origem dessa falta de importância simbólica dos "anexos".

Nessa disputa de classificações para estabelecer a definição legítima do embrião, o informante inverte a ordem do surgimento dos conceitos, como se o conceito de pré-embrião não fosse invenção recente. O profissional especula outros parâmetros para estabelecer a condição de "indivíduo": "Será que é indivíduo na hora em que respira? Será que é um indivíduo na hora em que começa a ter atividade neurológica? Quando ele começa a ter memória intra-uterina?". Os parâmetros que representam essa condição são: funções vitais como a respiração, que permitem a viabilidade; a atividade neurológica, um dos critérios para definir entre morto e vivo; a memória e a atividade neural como índices do sujeito consciente de si. O raciocínio desse médico baseia-se na tentativa de "reconhecer em uma forma natural a presença de uma forma social", no caso, o indivíduo ou pessoa (Strathern 1992:141). A biologia, citada por ele tantas vezes, seria base material do epifenômeno social (Laqueur 1992).

Nem todos usaram descrições biologizantes na argumentação, mas a referência a questões legais foi preocupação constante dos profissionais de reprodução humana. Quando perguntado sobre a manutenção de embriões extracorporais, um médico do serviço público de infertilidade colocou: "É caro e é um problema, porque o embrião é protegido por lei". Perguntei que estatuto atribuir ao embrião:

Você obedece à lei. Em tese, qualquer matéria viva tem que ter alguma, principalmente o embrião, quer dizer; é um pré-homem. É um pré-humano. Todos nós fomos aquilo. Se você manipular aquilo, teoricamente você poderia ter sido manipulado antes. Se você mata aquilo, você mata não um homem, mas um pré-homem, um projeto de homem. Rigorosamente, você está cometendo um pré-homicídio ou um homicídio de um pré-indivíduo.

Esse médico definiu a condição de pessoa do embrião em termos filosóficos, como primórdio do ser humano, condição universal da existência de todos. ${ }^{16}$ Durante reunião de equipe de embriologistas, em que se discutiram critérios técnicos de seleção e de exclusão de embriões para transferência, a linguagem permaneceu técnica. Nem em termos filosóficos nem em termos afetivos evocou-se o caráter de pessoa, mas sim a sua viabilidade em função de aspectos da morfologia durante o desenvolvimento: representou-se um indivíduo biológico. Uma profissional entrevistada disse que, fora da barriga da mãe, não havia embrião, só pré-embrião. Ela não considerava problema o descarte dos embriões que não se desenvolvessem 
nos meios de cultura providenciados no laboratório. Dizer que o ente é embrião apenas no útero materno é defini-lo de forma relacional, como também reconhecer que, se os técnicos de laboratório pararem os procedimentos para o cultivo, o embrião não se desenvolverá autonomamente. Representa-se aqui o embrião como pessoa, em imagem que privilegia as relações sociais, enquanto na maioria dos exemplos aparece o indivíduo, figura que oculta as relações. A informante nega a condição humana do embrião extracorporal.

Alguns profissionais atribuíram o estatuto de pessoa ao embrião. Uma embriologista entrevistada comentou sobre a norma do serviço público de reprodução que visa manter os embriões congelados por até cinco anos. Se o casal não solicitar a transferência nesse prazo, receberá o embrião de volta. Ela reconhece que, se o casal não encaminhar o embrião imediatamente para um laboratório de criopreservação, ele "morrerá" (sic). Comenta a notícia de um casal que, não desejando filhos após ter trigêmeos, recebeu o tubo com seus embriões congelados de volta. O marido guardou-os na porta do carro para dar sorte. A embriologista, contrária ao uso de embriões viáveis em pesquisa, escandalizou-se porque os embriões iriam morrer, embora reconhecendo que outros não tivessem consciência disso. O contexto do embrião altera as representações a seu respeito (cf. Novaes e Salem 1995): uma vez tendo alcançado seus objetivos reprodutivos, aquele que fora antes um projeto de filho é significado depois como talismã.

Nas entrevistas e na observação etnográfica, caracterizou-se o embrião de diversas formas. Será buscado nas páginas de opinião se há padrões nos modos de representar o embrião no debate sobre o seu uso para pesquisa.

\section{Ser ou não ser: o estatuto dos embriões humanos extracorpo- rais e a pesquisa com células-tronco}

No princípio, o debate sobre o uso de embriões humanos em pesquisa estava englobado no debate sobre clonagem humana. Opunha-se à clonagem ruim, a reprodutiva - em que se transfere o "embrião clonado" para o útero a fim de gerar "bebês-cópias"-à clonagem terapêutica — quando a técnica seria utilizada para a produção de tecidos para doação a partir de embriões (Luna 2001a).

A Igreja Católica é um dos interlocutores mais presentes no debate sobre o estatuto do embrião humano. Mesmo documentos religiosos respaldam-se nos conceitos biológicos (Luna 2002b). Em artigo sobre família e bioética, o arcebispo emérito da Arquidiocese do Rio de Janeiro, Dom Eugênio Sales (2002), um dos mais tradicionais expoentes da ala conservadora da Igreja 
Católica, citando diversos documentos do magistério católico, afirma: "no momento em que o óvulo é fecundado, inaugura-se uma nova vida que não é aquela do pai ou da mãe, mas de um novo ser humano que se desenvolve por conta própria". E "a manipulação e a destruição de embriões humanos não são moralmente aceitáveis, nem mesmo se destinados a um objetivo em si bom". Embora critique a "visão materialista do homem" e o direito resultante de procedimentos consensuais que "pode legalizar qualquer aberração", esse artigo, ao defender o embrião, não o caracteriza como dotado de alma. Outrora, a presença de alma seria cerne do debate, ponto não explicitado na argumentação do arcebispo emérito (cf. Franklin 1991). O arcebispo defende a teoria concepcionista de inauguração da vida, traz representações do desenvolvimento autônomo do embrião, um indivíduo que não depende do pai e da mãe, e critica perspectivas utilitaristas em que o benefício de outrem ultrapassa o valor da vida do indivíduo. ${ }^{17}$

Alguns textos aprofundam a análise do processo biológico. Lygia Veiga Pereira (2002b), professora no Instituto de Biociências da Universidade de São Paulo (USP), em artigo que aborda o debate sobre a clonagem humana na ONU, recorda que até 1997, com "o surgimento da ovelha Dolly, a criação de um embrião animal começava obrigatoriamente com a fusão de um óvulo com um espermatozóide". Ela diferencia a clonagem com finalidade terapêutica da clonagem com fins reprodutivos, propondo o uso entre aspas do termo "embrião" quando se fala do resultado da técnica de transferência nuclear para óvulos enucleados, "para lembrar que não é resultado da fecundação de um óvulo por um espermatozóide". A cientista afirma que o processo biológico diferente faculta a designação distinta do ente resultante. Essa diferenciação sutil serve para descolar a noção de pessoa do resultado de procedimentos de manipulação de material biológico humano em laboratório que não se dê através da fertilização.

Ao seguir a mesma tendência, Mayana Zatz (2004), professora de genética humana e médica da USP, coordenadora do Centro de Estudos do Genoma Humano do Instituto de Biociências da USP, distingue célulastronco pluripotentes obtidas sem fertilização, por meio da transferência nuclear (do núcleo de célula adulta para óvulo enucleado), das obtidas por meio da fertilização. Ela reconhece ser difundida a crença de que o início da vida ocorre na fertilização. Zatz aponta a criação de células pluripotentes por transferência nuclear como procedimento essencial para pesquisa. Fica implícito que esta seria a solução para o problema ético: sem fertilização não se fala em início da vida. Por não ter surgido de fertilização, não se poderia chamar de embrião, menos ainda de pessoa, o ente que originou as células-tronco pluripotentes. 
Há dois aspectos quanto aos argumentos de Pereira e Zatz: o primeiro é estratégia retórica, o segundo tem caráter simbólico. Designar o embrião ou qualquer ente por outro termo tem efeito retórico: mudar o nome é mudar a essência, expediente usado na Inglaterra com a designação de pré-embrião como arma para vencer no debate parlamentar e garantir a autorização da pesquisa com embriões de poucos dias (Mulkay 1997). Quanto ao aspecto simbólico, negar a fertilização é negar um dos marcos biológicos de início da vida. Em representações ocidentais de parentesco (Schneider 1968), se a condição de pessoa inicia com junção do material biogenético dos pais, na inexistência desse processo não há pessoa.

Alguns especialistas da medicina de reprodução humana opinam sobre o aumento do número de embriões criopreservados no Brasil (Nogueira 2002). ${ }^{18}$ Para José Franco Júnior, “a célula merece respeito, mas fora do corpo da mulher não tem vida". Segundo Roger Abdelmassih, "o embrião só pode ser considerado vivo quando ele se fixa no útero materno". Ambos consideram que o meio é essencial para considerar o embrião vivo, mais especificamente a implantação no útero, condição de viabilidade. Em vez de um indivíduo em si, eles representam o embrião como ser relacional, estado em que é pessoa. Em posição semelhante a profissionais entrevistados, Luiz Fernando Dale afirma: "o que congelamos é um amontoado de células com potencial de se tornar um embrião. A vida começa quando é possível registrar o primeiro batimento cardíaco, o que só acontece após a quinta semana de gestação". Trata-se de uma posição gradualista que contrasta a indiferenciação inicial, "o aglomerado de células", com etapa posterior e superior do desenvolvimento biológico. A possibilidade técnica de registrar o batimento cardíaco permitiria identificar o início da fase, representando o indivíduo em si.

Manifestam-se vozes divergentes da comunidade científica. Alice Teixeira Ferreira (2004), professora de biofísica da Universidade Federal de São Paulo (UNIFESP), critica o desvio dos estudos bem-sucedidos com células-tronco adultas para se fazer "pajelança com as células-tronco embrionárias". Contrária à destruição de embriões humanos, a autora afirma que, se fossem montes de células sem vida, não poderiam ser usados no tratamento de doenças. Alerta para riscos do tratamento com células de embriões: rejeição e possibilidade de formarem tumores. Adverte que produzir células geneticamente compatíveis na clonagem terapêutica, evitando a rejeição, resultaria em células dotadas do mesmo defeito genético do paciente. O ritual religioso de cura mencionado no título indica expectativas exageradas nos tratamentos com células-tronco embrionárias. A autora aponta os riscos dos tratamentos, mas não explicita o estatuto do embrião, embora considere haver vida nas células. 
Ao discutir a questão jurídica, o jornalista Luiz Paulo Horta (2005) aborda a ação de inconstitucionalidade impetrada pelo procurador-geral da República Cláudio Fonteles contra o artigo da Lei de Biossegurança que autoriza o uso de células-tronco embrionárias. Horta discorda da acusação de que convicções religiosas influenciaram o procurador. O uso de célulastronco embrionárias supõe a destruição do embrião, coisa inadmissível do ponto de vista religioso, ou "idealista" (sic). Horta identifica os cientistas com uma vertente "pragmática" (sic), para quem não interessa a definição de marcos biológicos do início da vida (exemplo: constituição dos centros nervosos), mas as possibilidades práticas da pesquisa. Cita a pesquisadora Lygia Pereira: "a questão não é se o blastocisto é vida ou não, mas se a sociedade vai tolerar que se interfira nesse blastocisto".

Horta contrapõe a proposta de Pereira, na qual a sociedade decide em função de resultados concretos da pesquisa, e absolutos, como o postulado de inviolabilidade da vida humana na Constituição. Segundo ele, a "defesa da dignidade humana não pode ficar ao sabor de percepções variáveis". Enquanto Pereira, em perspectiva relacional, defende a arbitragem pela sociedade do que fazer com um ente biológico (nomeado blastocisto e não embrião), Horta retrata no embrião o indivíduo como valor de Dumont (1997, 1992). Aproximando-se do artigo de D. Eugênio Sales, em "sua defesa de absolutos e na crítica ao utilitarismo", o autor assume posição metafísica que nega o caráter culturalmente construído de seu próprio esquema de valores e da atribuição da condição de pessoa ao embrião. A dignidade da pessoa humana e a inviolabilidade da vida são valores transcendentes, estão na esfera do sagrado. ${ }^{19}$

Representantes da comunidade científica e de setores de ponta da medicina assumem posições religiosas, a exemplo do dr. Roger Abdelmassih (2005), especialista em medicina de reprodução, que se diz de "formação e convicção religiosa católicas", e "católico praticante". O autor lista definições do estatuto do embrião: "conjunto de células, mas não é vida"; "é vida a partir da formação do sistema neural com 15 dias de existência", e a sua própria: "o embrião torna-se uma vida, com todos os direitos inerentes, a partir do momento de sua implantação no útero materno - a partir de quando é alimentado e tem condições de desenvolver-se"; portanto, o embrião congelado não é vida. Para Abdelmassih, debates de ordem religiosa, jurídica e econômica não devem impedir a cura de "condições de saúde" "que ferem os princípios da dignidade do viver". Nenhum debate "poderia estar acima e à frente do direito à vida de seres vivos que sofrem sem esperança para os seus males, para os quais Deus misericordioso está propondo soluções por meio do conhecimento dos homens". Impedir essa esperança seria "incompatível com a dignidade do viver" e constituiria "o pecado maior". 
O médico evoca valores religiosos em defesa da possibilidade de cura. Arrola modos de caracterizar o embrião: sem individualização não é ser humano, sem sistema nervoso, tampouco: faltam-lhe a singularidade (cf. Simmel 1971) e a racionalidade essenciais. Seu critério é relacional: a implantação no útero é condição de desenvolvimento, impossível no embrião isolado. O médico relê a ética religiosa para adequá-la ao dever da ciência de aliviar o sofrimento humano, valor iluminista por excelência, e neutraliza argumentos discordantes do campo da religião e do direito.

Há argumentos que reconceitualizam a vida. Renato J. Costa Valladares (2005), professor de matemática, recorda que a inviolabilidade da vida humana é um valor construído ao longo dos séculos, estendido à vida intra-uterina e recentemente, com o avanço técnico, à preservação da vida embrionária extra-uterina. Valladares, usando "matemática elementar" e "senso comum", demonstra que a "Natureza destina à morte grande quantidade de óvulos" e "quantidade ainda maior de espermatozóides". A técnica de fertilização in vitro cria mais embriões do que é possível implantar, destinando-os ao congelamento e à espera "da morte certa". Efetivadas as terapias com células-tronco, células desses embriões, "indivíduos potenciais", podem continuar "a viver integradas a outro indivíduo, cuja vida melhorarão". Compara esse procedimento ao transplante de órgãos, retirados de um indivíduo destinado a morrer, e que continuam a viver em outro indivíduo. Embora chamando o embrião de indivíduo potencial, o autor não o considera dotado de vida individualizada, um sujeito ou pessoa, mas como células vivas que continuariam existindo em outro indivíduo. Esta seria a possibilidade de escapar da morte, além de auxiliar doentes. A vida biológica continua, mas não a vida como pessoa.

Os cientistas buscam meios de contornar a destruição de embriões para continuar a pesquisa com células-tronco. Marcelo Leite (2005), doutor em ciências sociais e colunista da Folha de São Paulo, um dos principais articulistas de divulgação científica da imprensa brasileira, anuncia dois avanços. A empresa americana Advanced Cell Technology retirou por biópsia uma célula de um embrião de três dias e dela obteve células-tronco, sem inviabilizar o embrião que permaneceu capaz de gerar um organismo. Experimento no Instituto de Tecnologia de Massachusetts (MIT) manipulou um gene de célula adulta que, inserida em óvulo enucleado, virou um embrião anormal incapaz de implantação no útero. Segundo Leite, criou-se "um não-embrião": para não destruir um embrião fisicamente, destruiu-se seu estado de embrião. A viabilidade é o critério: o embrião continua viável no primeiro exemplo e, no segundo, cria-se um ente de desenvolvimento inviável, mas capaz de gerar células-tronco. O objetivo não seria apenas renomear o ente estrategicamente, mas criar biologicamente outro de estatuto diferenciado do humano. 
A médica Marlene Nobre (2005), em artigo sobre aborto de anencéfalos, argumenta que as razões contrárias ao aborto provocado não são "exclusivamente da alçada da religião", mas "têm raízes na própria ciência". ${ }^{20}$ Baseada nos embriologistas Moore e Persaud, afirma que "o zigoto e o embrião inicial são organismos humanos vivos, nos quais estão fixadas todas as bases do indivíduo adulto". A seqüência "zigoto, feto, criança, adulto, velho" seria um contínuo cuja interrupção causa danos à vida. A "Teoria Neodarwiniana" seria insuficiente para explicar a evolução, o que a leva a defender a "Teoria do Planejamento Inteligente". Pesquisas revelam registros (imprints) mnemônicos no zigoto com evidência precoce da riqueza da personalidade na embriogênese. Isto demonstra "competência do embrião: capacidade para autogerir-se mentalmente; adequar-se a situações novas; selecionar situações e aproveitar experiências". Conclui que a vida do embrião pertence "exclusivamente a ele mesmo", por isso, haveria "fortes razões científicas" para recusar o aborto, mesmo no caso da anencefalia. O portador dessa deficiência faz parte da "diversidade genética", merecendo preservação e respeito. Sugere que a mulher grávida de anencéfalo precisa de apoio psicológico contra (sic) seu sentimento de culpa, que pode incitá-la à violência contra o feto. "Seria importante inclinar seu coração à compaixão e à misericórdia, mostrando-lhe o real significado da vida".

O artigo mescla os discursos religioso e científico, apoiando-se no último, em função de a cientificidade na cosmologia ocidental moderna servir de garantia da verdade: a percepção de que as ciências naturais revelam a realidade (Martin 1997). Ao afirmar a continuidade da vida humana a partir da fecundação, a autora defende a "Teoria do Planejamento Inteligente". ${ }^{21}$ O embrião humano desde o início possui características de indivíduo: tem "fixadas as bases do indivíduo adulto" (provavelmente bases genéticas) e manifesta personalidade própria ou memória em imprints (registros). Sua descrição do embrião humano representa o indivíduo ocidental (Dumont 1992, 1997): tem competências de "se autogerir", adequar-se a situações e selecioná-las, aproveitar experiências, por isso, sua vida pertence a ele mesmo. Nobre apóia-se em "razões científicas" e invoca a diversidade genética para preservar o feto, porém muda o discurso na conclusão. Assume linguagem psicologizante, advertindo que a gestante de anencéfalo necessita de "ajuda para trabalhar seu sentimento de culpa", mas conclui com discurso religioso: "inclinar seu coração à compaixão e à misericórdia". Pretende mostrar o "real significado da vida", interpretação que permanece em aberto: sua definição religiosa? A reformulação da linguagem científica em moldes religiosos? Lembrando a epígrafe: o significado da vida reside nos conceitos da biologia, últimos refúgios da transcendência. 


\section{Considerações finais}

Este texto inicia indagando sobre o estatuto do embrião humano no contexto extracorpóreo. As descrições biologizantes do embrião feitas pelos entrevistados e presentes nos textos analisados são informadas pela ideologia universalista, da qual o cientificismo é aspecto integrante (Duarte 2004). A definição do estatuto do embrião de laboratório relaciona-se a questões éticas com implicações práticas: é permitido descartá-lo? É lícita a sua criopreservação? O que fazer dos embriões "abandonados pelos pais"? Deve-se autorizar o uso de embriões como material de pesquisa, tendo em vista possibilidades de benefícios para curar doenças, na dependência do desenrolar do avanço científico?

Muitos entrevistados e alguns textos afirmam a condição de pessoa do embrião, discordando, porém, acerca de quando e como identificá-la. A construção dessa categoria de pessoa se dá principalmente em termos de dados da biologia. Alguns acentuam o aspecto relacional em função da necessidade de inserção do embrião no "meio" em que seu desenvolvimento é possível: o útero materno. Ao tomar referenciais de desenvolvimento autônomo e individualização, como a gravidez anembrionada, nem mesmo a inserção no útero basta para esse reconhecimento. Enfatizaram-se diferentes marcos físicos como referência para a atribuição dessa condição de pessoa. Os valores da individualidade e da autonomia, característicos da ideologia do individualismo moderno (Dumont 1997, 1992), estão subjacentes aos diferentes marcos: da presença do DNA de um indivíduo humano desde a concepção até as etapas em que a massa celular se diferencia e autonomiza com a emergência da linha primitiva ou com a diferenciação dos anexos.

Tais descrições se atêm a critérios fisicalistas tanto para defender uma noção essencialista e inaugural da condição de pessoa, como para afirmar uma noção gradualista de sua emergência. Os atributos físicos no desenvolvimento embrionário seriam naturais, considerados universais segundo a cosmologia surgida no Iluminismo, que toma a natureza por base da realidade. As descrições biologizantes pretendem a universalidade da condição de pessoa do embrião no estágio de desenvolvimento referido (concepção, emergência da linha primitiva, formação do saco gestacional com batimento cardíaco). A essência humana estaria dada na biologia. Partidários da instauração imediata da condição de pessoa na fertilização argumentarão pela continuidade do processo desde a fusão dos gametas, enquanto partidários do desenvolvimento gradual da condição de pessoa usarão outro marco físico de referência, assumindo-se a forma humana gradativamente. Também a negação da condição de pessoa nos primeiros estágios baseia-se 
em descrições fisicalistas dos embriões iniciais como aglomerados de células sem forma nem individualidade.

Marco cosmológico ocidental, o dualismo cartesiano é distinto de dualismos anteriores por carecer de fundamento religioso. Dele se inventa o corpo ocidental: limite da individualidade, acessório da pessoa, descentrado do sujeito, compreendido a partir do paradigma da máquina (Le Breton 1995). Ao esvaziar o corpo dos vestígios da alma, os cientistas ficavam livres para examinar o corpo fisicamente, como coisa, o que permitiu o desenvolvimento da biologia experimental e da biomedicina (A. Strathern 1996). Surgida no Iluminismo, a ênfase na natureza como base da realidade e fundamento epistêmico para questões da ordem social (Laqueur 1992), associada ao desenvolvimento biotecnológico acelerado do final do século XX, levanta um paradoxo. Se o dualismo cartesiano esvaziara o corpo de qualidades morais, a emergência de entes de laboratório (embriões, DNA, gametas) vem cercada do esforço de definir seu estatuto moral a partir de atributos biológicos. Isto desloca valores transcendentes, como a dignidade humana para o genoma e para os embriões (cf. Lévi-Strauss 1982; Rabinow 1999).

Franklin (1995) refere-se ao embrião como entidade de parentesco liminar que preenche critérios de aparentamento, pois teria vínculos genéticos com os "pais". Trata-se de um ente de parentesco no sentido simbólico: ancestral comum de toda a humanidade, condição pela qual todos passaram. Como indivíduo singular, o embrião tem potencial de se tornar um ser humano completamente desenvolvido. Por outro lado, o laço de parentesco com o embrião é liminar, por ser um ente microscópico, irreconhecível imediatamente como ser humano. O embrião gerado por fertilização in vitro estaria situado entre natureza e cultura, ascendendo à existência de modo orgânico e tecnológico (Franklin 1995).

Constata-se o predomínio de representações biologizantes do embrião para caracterizar ou negar sua condição de pessoa, com diferentes marcos de instauração entre os informantes e nos textos sob análise. Essas representações biologizantes tanto dizem respeito ao embrião formado em laboratório, quanto ao embrião já implantado no útero materno. A condição de pessoa do embrião caracteriza-se por representações de autonomia e singularização em face do corpo materno ou da massa celular de que é composto. Tais valores indicam a configuração individualista da qual essa noção de pessoa é tributária. Mesmo quando se representa a necessidade de inserção no útero, este significa mais um meio para o desenvolvimento do indivíduo do que a relação com a pessoa da mãe. Isto confirma a conclusão de Salem (1997): a caracterização do embrião como pessoa baseada em critérios biológicos 
oculta as relações sociais, particularmente o parentesco, representando-o como ente desprovido delas, o ideal de indivíduo.

Há vários critérios para atribuir a um ente a condição de pessoa e considerá-lo sujeito de direitos. Invocam-se características biológicas para defender posições diferentes. Fundam-se absolutos em atributos humanos essenciais. Se no discurso teológico cristão os atributos eram a presença da alma, esses valores metafísicos deslizam para a condição material do ser. Nessa condição material, física ou biológica, ancoram-se os critérios: formato humano, funções vitais, fixação no útero materno, genoma individual formado na fecundação. Estes ditos "dados biológicos" são construídos pelo olhar de quem os julga: ao embrião faltaria organização e diferenciação para ser considerado um ser humano individualizado de mesmo nível que uma pessoa nascida. A falta de autoconsciência e de sensibilidade física aproximaria o ente da condição vegetal e o afastaria do que se considera humano.

Enquanto a controvérsia sobre a liberação da pesquisa com embriões, presente na imprensa (Segatto e Termero 2004) ${ }^{22}$ e no debate legislativo brasileiro (Cesarino 2006), opôs as luzes da ciência ao obscurantismo da religião com seus conceitos metafísicos, nos discursos para se falar do embrião foram encontradas a preeminência de argumentos biológicos e a raridade de referências metafísicas ou religiosas - salvo a noção filosófica de dignidade humana. Há embate entre discursos de caráter religioso ou metafísico e discursos científicos biologizantes.

Quando a cientista alega que a sociedade pode arbitrar no Direito se é tolerável o uso de blastocistos humanos com fins de beneficiar pessoas que sofrem, levanta-se o imperativo ético: a proteção à vida humana. Buscam-se técnicas para contornar objeções éticas e garantir a viabilidade do embrião ou para criar um "não-embrião" utilizável. A útima posição associa-se a estratégias retóricas para dissociar o produto das técnicas de laboratório da figura do embrião humano: não é embrião porque se formou de transferência nuclear ou de partenogênese, e não da fertilização. Tal estratégia, associada à designação do embrião por outros termos (blastocisto), assume importância, pois cada vez mais grupos pró-vida tentam equacionar embrião e pessoa. Por um lado, representantes da comunidade científica e médica apóiam-se no discurso religioso e em seus valores, como compaixão pelo sofrimento alheio e bondade divina, para assegurar o direito do uso de embriões para a pesquisa. Por outro, portadores do discurso religioso garantem a base científica de suas afirmações. Um dos exemplos encontra-se nos documentos da Igreja Católica, quando esta diz basear-se em "evidência [...] da moderna ciência genética" para afirmar que o embrião é ser humano a partir da fertilização. Outro exemplo é a mescla do discurso científico e do discurso religioso para 
estabelecer valores transcendentes, quando se defende a "Teoria do Planejamento Inteligente" e se declara a existência de memória e de personalidade desde o zigoto, o que revelaria seu "verdadeiro significado".

Outro ponto desse debate, caro aos defensores do uso de embriões humanos como material de pesquisa, é a contraposição de "viabilidade" e "potencial". O potencial de vida do embrião fica nulo se mantido em meio impeditivo do desenvolvimento. Introduz-se o problema da viabilidade: o desenvolvimento do embrião fora do útero é inviável. Na argumentação oposta, o embrião não é apenas potencial de ser humano, mas uma pessoa já realizada em sua essência pela identidade individual de seu DNA desde a fecundação.

O quadro do debate sobre o estatuto do embrião evidencia uma situação de drama social. Na controvérsia sobre a condição a ser atribuída a esse ente, grupos e agentes sociais com posições divergentes enfrentam-se. Trata-se da expressão e da redefinição de pontos cruciais na constituição da sociedade que estão no cerne de sua cosmologia: o que é vida? O que é pessoa? Ao contrariar análises superficiais que desenham uma oposição entre ciência e religião, ou entre seus representantes legítimos, o exame dos artigos sugere quadro mais complexo, em que as posições não se colocam de forma dualista. O ponto comum na controvérsia é apelar para a base natural, a fim de garantir a veracidade da argumentação. Nesse campo, onde se debatem as definições legítimas de vida e pessoa, tenta-se fundamentar a existência desses atributos metafísicos essenciais na Natureza, ou em sua versão moderna para os seres vivos - a Biologia. Questões discutidas muito antes da emergência da biologia como ciência necessitam do calço da "ciência da vida" para alcançar o estatuto de verdade. Ao contrário da expectativa iluminista de que o avanço do conhecimento científico viesse a solapar questões religiosas e metafísicas, estas ressurgem no debate, travestidas nos conceitos biológicos, os últimos refúgios da transcendência.

Recebido em 01 de fevereiro de 2006

Aprovado em 06 de junho de 2007

Naara Luna é doutora em antropologia pelo PPGAS, Museu Nacional, UFRJ. Atualmente contando com bolsa de fixação de pesquisador da FAPERJ no Núcleo de Tecnologia Educacional para a Saúde (NUTES) - UFRJ. E-mail: $<$ naara_luna@ig.com.br>. 


\section{Notas}

${ }^{1}$ São citados jornais e revistas brasileiros de grande circulação. Seus leitores são predominantemente das camadas médias e altas da sociedade. Quanto às matérias de divulgação científica, os periódicos têm postura liberal, tendendo a defender as posições da comunidade científica, embora veiculem opiniões diversificadas.

${ }^{2}$ Ao continuar o levantamento na imprensa, constatou-se que as matérias de opinião e as cartas freqüentes dos leitores durante o debate legislativo, após a aprovação da lei e depois da ação de inconstitucionalidade, cessaram em seguida.

${ }^{3}$ Redução embrionária é o aborto seletivo de embriões em gestação múltipla, procedimento usado quando vinga número superior ao seguro para gestante e fetos (Corrêa 2001).

${ }^{4}$ Nos depoimentos e nos textos, raramente eram argumentadas definições de caráter social ou metafísico em termos sociais ou metafísicos, pelo contrário, geralmente fundamentava-se a opinião em dados biológicos: a vida inicia na concepção.

${ }^{5}$ Sobre os processos de biologização e genetização do parentesco cf. Luna (2005).

${ }^{6}$ No original: "the phase in which it enfolds its own potential" (minha tradução).

${ }^{7}$ A linha primitiva é uma estrutura correspondente ao primórdio da medula espinhal, estrutura constantemente adotada como marco de referência (Salem 1997; Strathern 1992).

${ }^{8} \mathrm{O}$ "Comunicado Final da IV Assembléia Geral da Pontifícia Academia para a Vida", referindo-se à constituição do genoma individual na fertilização, afirma sobre o concepto: "sua natureza tem como base orgânica a presença de um genoma especificamente humano" (itálicos originais). Disponível em: < http://www.vatican.va/roman_curia/ pontifical_academies/acdlife/documents/rc_pa_acdlife_doc_28091998_final-doc_ po.html > . Acesso em 21/08/2004. Luna (2002b) examina a posição da Igreja Católica sobre técnicas de reprodução assistida e estatuto do embrião.

${ }^{9}$ Palestra "Manipulação genética e reprodução assistida" proferida pelo dr. Roger Abdelmassih em 23/09/2002, no Instituto dos Advogados de São Paulo.

${ }^{10}$ Descrever o embrião fora do corpo como um monte, bolo ou aglomerado de células é a representação mais freqüente nos artigos de imprensa escritos por aqueles que não lhe atribuem a condição de pessoa e defendem o uso do embrião humano em pesquisas.

${ }^{11}$ Programa exibido pela Rede Globo em 20/04/2001. 
${ }^{12}$ Segundo Leite (1995), nos Estados Unidos a organização judiciária e a administrativa e o processo civil e criminal variam entre os estados. Não há lei federal única sobre a reprodução assistida com definição do estatuto do embrião.

${ }^{13}$ Comunicação apresentada em 26/09/2002, no VI Congresso Brasileiro de Reprodução Assistida.

${ }^{14}$ Segundo Strathern (1988:104), no conceito ocidental, "propriedade" se constrói como uma relação entre pessoas e coisas, em que as coisas são externas às pessoas que as possuem.

${ }^{15}$ Isto ocorre através de registros nos laboratórios das unidades de reprodução assistida.

${ }^{16}$ Ao analisar o debate parlamentar na Inglaterra para regulamentar a prática da reprodução assistida (Human Fertilization and Embriology Act), Franklin (1999) constatou ali a representação do embrião como um ancestral comum a todos, um fato universal de humanidade compartilhada, uma vez que todos os seres humanos já foram embriões.

${ }^{17} \mathrm{Na}$ "Instrução sobre o respeito à vida humana nascente e à dignidade da procriação", a seção sobre o respeito aos embriões humanos abre com três parágrafos de análise doutrinária de dados biológicos e apenas no quarto parágrafo menciona a alma: "nenhum dado experimental, por si só, pode ser suficiente para fazer reconhecer uma alma espiritual" (Congregação para a Sagrada Doutrina da Fé, 1987, p. 21).

${ }^{18}$ No artigo, depõem diretores de serviços particulares da medicina de reprodução humana, nos estados de São Paulo e Rio de Janeiro. Esses especialistas são fontes freqüentes na mídia.

${ }^{19}$ Rabinow discorre sobre a formulação dos princípios de dignidade da pessoa humana como ser racional e capaz de autonomia feita por Kant, sua continuidade entre filósofos e juristas, e a retomada após a Segunda Guerra como princípio fundante da existência humana (1999). Compara o privilégio da autonomia nos Estados Unidos ao da dignidade na França, com respeito à disposição da pessoa sobre o próprio corpo. Ele pergunta como articular o sagrado de forma sensível para a sociedade atual em relação ao corpo humano.

${ }^{20}$ Incluiu-se o artigo por sua pertinência na controvérsia do estatuto do embrião desde a fecundação.

${ }^{21}$ Também designada de "Teoria do Design Inteligente" ou "teoria do projeto inteligente". Nos Estados Unidos, grupos que afirmam a base científica das teses criacionistas defendem a inclusão dessa teoria no currículo escolar junto com a teoria da evolução das espécies (Celestino 2005).

${ }^{22}$ Esta perspectiva revela-se no título "A guerra das células-tronco: depois da vitória no Senado, pacientes preparam a luta contra o lobby religioso na Câmara, contrário às pesquisas com embriões". 


\section{Referências bibliográficas}

ABDELMASSIH, Roger. "O pecado maior". O Globo, Opinião, 14/03/2005, p. 7.

BOROJEVIC, Radovan. 2004. "Terapias celulares: promessas e realidades". Ciência Hoje, 35(206):37-39.

BOURDIEU, Pierre. 1996. A economia das trocas lingüísticas: o que falar quer dizer. São Paulo: EDUSP.

CANNELL, Fenella. 1990. "Concepts of parenthood: the Warnock report, the Gillick debate, and modern myths". American Ethnologist, 17(4):667-86.

CELESTINO, Helena. "Involução americana: EUA vivem batalha entre defensores da evolução e do criacionismo religioso". O Globo, O Mundo, 21/08/2005, p.32.

CESARINO, Letícia Maria Costa da Nóbrega. 2006. Acendendo as luzes da ciência para iluminar o caminho do progresso: uma análise simétrica de Lei de Biossegurança Brasileira. Dissertação de mestrado em antropologia social, Universidade de Brasília.

COMITÊ NACIONAL DE BIOÉTICA. 1997. "Identidade e estatuto do embrião". SEDOC 29(261):540-62.

CONGREGAÇÃO PARAA DOUTRINADA FÉ. 1994 [1987]. Instrução sobre o respeito à vida humana nascente è dignidade da procriação: respostas a algumas questões atuais. São Paulo: Paulinas.

CONKLIN, Beth A. \& MORGAN, Lynn M. 1996. "Babies bodies and production of personhood in North America and a native amazonian society". Ethos, 24(4):657-94.

CONSELHO FEDERAL DE MEDICINA. Resolução no 1358/92 do CFM. In: E. O. Leite. 1995. Procriações artificiais e o Direito: aspectos médicos, religiosos, psicológiCos, éticos e jurídicos. São Paulo: Editora Revista dos Tribunais. pp. 429-432.
CORRÊA, Marilena Villela. 2001. Novas tecnologias reprodutivas: limites $d a$ biologia ou biologia sem limites? Rio de Janeiro: EdUERJ.

CORREIA, Clara Pinto. 1997. The ovary of Eve: egg and sperm and preformation. Chicago/ Londres: University of Chicago Press.

DAMATTA, Roberto. 1997. Carnavais, malandros e heróis: para uma sociologia do dilema brasileiro. Rio de Janeiro: Rocco.

DINIZ, Débora. 2003. "Tecnologias reprodutivas conceptivas: o estado da arte do debate legislativo brasileiro". Jornal Brasileiro de Reprodução Assistida, 7(3):10-19.

DUARTE, Luiz Fernando Dias. 2004. "A pulsão romântica e as ciências humanas no Ocidente". Revista Brasileira de Ciências Sociais, 19(55):5-18.

DUMONT, Louis. 1992. Ensaios sobre o individualismo: uma perspectiva antropológica sobre a ideologia moderna. Lisboa: Dom Quixote. . 1997. Homo hierarchicus: o sistema de castas e suas implicações. 2a .ed. São Paulo: EdUSP.

FERREIRA, Alice Teixeira. "A pajelança com as células-tronco". O Globo, Opinião, 20/08/2004, p. 7.

FRANKLIN, Sarah. 1991. "Fetal fascinations: new dimensions to the medical-scientific construction of fetal personhood". In: S. Franklin; C. Lury \& J. Stacey (orgs.), Off-Centre: feminism and cultural studies. Lancaster: HarperCollins Publishers. pp. 190-205. . 1995. "Postmodern procreation: a cultural account of assisted reproduction". In: F. G. Ginsburg \& R. Rapp (orgs.), Conceiving the new world order. Berkeley/ Los Angeles/ 
Londres: University of California Press. pp. 323-45. . 1999. "Making representations: the parliamentary debate on the human fertilisation and embryology act". In: J. Edwards et alii, Technologies of procreation: kinship in the age of assisted conception. 2.ed. London/ New York: Routledge. pp. 127-169.

FYFE, Wendy. 1991. "Abortion acts: 1803 to 1967". In: S. Franklin; C. Lury \& J. Stacey (orgs.), Off-Centre: feminism and cultural studies. Lancaster: HarperCollins Publishers. pp. 160-174.

GIUMBELLI, Emerson. 2002. "Para além do 'trabalho de campo': reflexões supostamente malinowskianas". Revista Brasileira de Ciências Sociais, 17(48):91-107.

HIRSCH, Eric. 1999 [1993]. “Negotiated limits: interviews in South-East England". In: J. Edwards et alii, Technologies of procreation: kinship in the age of assisted conception. 2.ed. London/ New York: Routledge. pp. 91-121.

HORTA, Luiz Paulo. "O procurador pisou em falso?". O Globo, Opinião, 5/06/2005, p. 7.

INGOLD, Tim. 1990. "An anthropologist looks at biology". Man, (N.S.) 25(2):208-229.

JUNKER-KENNY, Maureen. 1998. "O status moral do embrião". Concilium, 275(2):60-72.

LA FONTAINE, J. S. 1985. "Person and individual: some anthropological reflections". In: M. Carrithers; S. Collins \& S. Lukes, The category of the person: anthropology, philosophy, history. Cambridge: Cambridge University Press. pp. 123-140.

LAQUEUR, Thomas. 1992. Making sex: body and gender from the greeks to Freud. Cambridge/ London: Harvard University Press.

LE BRETON, David. 1995. Anthropologie du corps et modernité. 3a.ed. Paris: Presses Universitaires de France.
LEAL, Ondina Fachel \& LEWGOY, Bernardo. 1995. "Pessoa, aborto e contracepção". In: O. F. Leal (org.), Corpo e significado: ensaios de antropologia social. Porto Alegre: Editora da Universidade/ NUPACS. pp. 57- 75.

LEITE, Eduardo Oliveira. 1995. ProcriaÇões artificiais e o direito: aspectos médicos, religiosos, psicológicos, éticos e jurídicos. São Paulo: Editora Revista dos Tribunais.

LEITE, Marcelo. "Embriões desarmados". Folha de S. Paulo, Ciência, 23/10/2005. Disponível em: <http://www.unicamp. br/unicamp/canal_aberto/clipping/outubro2005/clipping051023_folha. html\#4 >. Acesso em 19/01/2006.

LÉVI-STRAUSS, Claude. 1982. As estruturas elementares do parentesco. Petrópolis: Vozes.

LUNA, Naara Lúcia de Albuquerque. 2001a. "A clonagem como problema e seus lugares comuns". Ciência Hoje: Revista de Divulgação Científica da Sociedade Brasileira para o Progresso da Ciência, 30(176):45-47.

. 2001b. "Pessoa e parentesco nas novas tecnologias reprodutivas". Revista Estudos Feministas, 9(2):389-413. . 2002a. "Maternidade desnaturada: uma análise da barriga de aluguel e da doação de óvulos". Cadernos Pagu, 19:233-78. . 2002b. "As novas tecnologias reprodutivas e o estatuto do embrião: um discurso do magistério da Igreja Católica sobre a natureza". Revista Gênero, 3(1):83-100.

2004. Provetas e clones: teorias da concepção, pessoa e parentesco nas novas tecnologias reprodutivas. Tese de doutorado, Museu Nacional, UFRJ. .2005. "Natureza humana criada em laboratório: biologização e genetização do parentesco nas novas tecnologias reprodutivas". História, Ciências, SaúdeManguinhos, 12(2):395-417. 
MAUSS, Marcel. 1974. "Uma categoria do espírito humano: a noção de pessoa, a noção do 'eu'". In: Sociologia e antropologia. v.1. São Paulo: EPU/ EDUSP. pp. 207-39.

MARTIN, Emily. 1997. "Anthropology and the cultural study of science: from citadels to string figures". In: A. Gupta \& J. Ferguson. Anthropological locations: boundaries and grounds of a field science. Berkeley/ Los Angeles: University of California Press. pp. 131-146.

MULKAY, Michael. 1997. The embryo research debate: science and the politics of reproduction. Cambridge: Cambridge University Press.

NOBRE, Marlene. "Outra opinião: base científica". O Globo, 29/04/2005, p. 6.

NOGUEIRA, Danielle. "Depósito de embriões: clínicas de reprodução assistida não sabem o que fazer com os 11 mil óvulos fecundados que mantêm congelados". Domingo, ano 26, n. 1346, 17/02/2002, pp. 10-11.

NOVAES, Simone \& SALEM, Tania. 1995. "Recontextualizando o embrião". Estudos Feministas, 3(1):65-88.

PEREIRA, Lygia da Veiga. 2002a. Clonagem: fatos \& mitos. São Paulo: Moderna.

2002b. "A clonagem humana na ONU". O Globo, Opinião, 13/03/2002, p. 7.

PONTIFÍCIAACADEMIA PARAA VIDA. 1998. Comunicado Conclusivo da IV Assembléia Geral da Pontifícia Academia para a Vida. Disponível em: http://www.vatican.va/ roman_curia/pontifical_academies/ acdlife/documents/rc_pa_acdlife doc_28091998_final-doc_po.html . Acesso em 21/08/2004.

RABINOW, Paul. 1999. French DNA: trouble in purgatory. Chicago/ London: The University of Chicago Press.

SALEM, Tania. 1997. "As novas tecnologias reprodutivas: o estatuto do embrião e a noção de pessoa". Mana. Estudos de Antropologia Social, 3(1):75-94.

SALES, D. Eugenio de Araujo. "Questões de bioética". O Globo, Opinião, 23 fev. 2002, p. 7.

SEGATTO, Cristiane \& TERMERO, Maíra. "A guerra das células-tronco: depois da vitória no Senado, pacientes preparam a luta contra o lobby religioso na Câmara, contrário às pesquisas com embriões". Época, 18/10/2004, pp.100-107.

SCHNEIDER, David. 1968. American kinship: a cultural account. Englewood Cliffs: Prentice-Hall.

SIMMEL, Georg. 1971 [1908]. On individuality and social forms. Chicago: University of Chicago Press. Donald N. Levine (org.).

STRATHERN, Andrew J. 1996. Body thoughts. Ann Arbor: University of Michigan Press.

STRATHERN, Marilyn. 1988. The gender of the gift: problems with women and problems with society in Melanesia. Berkeley/ Los Angeles/ London: University of California Press. . 1992. Reproducing the future: essays on anthropology, kinship and the new reproductive technologies. Manchester: Manchester University Press. . 1999 [1993]. "Regulation, substitution and possibility." In: J. Edwards et alii. Technologies of procreation: kinship in the age of assisted conception. 2a.ed. London/ New York: Routledge. pp. 171-216.

TURNER, Victor W. 1957. Schism and continuity in an african society: a study of Ndembu Village life. Manchester: Manchester University Press.

VALLADARES, Renato J. Costa. "Células-tronco e bom senso". O Globo, Opinião, 15/07/2005, p. 7.

ZATZ, Mayana. "Esperança renovada". Folha de São Paulo, Ciência, 13/02/2004, p. A14. 
Resumo

Este artigo examina representações de embrião e feto humanos presentes no discurso de profissionais envolvidos com a medicina de reprodução humana e os serviços de infertilidade, além de textos publicados na grande imprensa. Enfocouse o debate sobre o estatuto do embrião fora do corpo, em particular, a polêmica sobre o uso de embriões humanos como material de pesquisa para a obtenção de células-tronco, área de investigação científica que traz a expectativa de cura de diversas doenças. Esse debate indica situações de "drama social" ou controvérsia, quando se exprimem questões cruciais na constituição de uma sociedade. Encontraram-se representações sobre o embrião e o feto humanos que lhes atribuem ou negam a condição de pessoa. A argumentação baseia-se em descrições de caráter biológico, invocando os discursos científico e religioso. Valores correntes da cosmologia ocidental moderna revelam-se nas descrições.

Palavras-chave: Embrião humano, Células-tronco, Construção social da pessoa, Biologização

\section{Abstract}

This article examines ideas concerning the human embryo and foetus present in the discourse of professional staff working in human reproductive medicine and infertility services, as well as texts published in the mainstream press. It focuses on the debate concerning the status of the embryo outside the body, in particular, the polemic surrounding the use of human embryos as research material for obtaining stem cells, an area of scientific investigation that raises the hope of cures for a wide range of diseases. This debate points to situations of 'social drama' or controversy that reveal critical questions for the constitution of society. Here ideas concerning the human embryo and foetus tend either to attribute or deny them personhood. Based on biological descriptions, but invoking both scientific and religious discourses, these arguments expose some of the contemporary values of modern western cosmology.

Key words: Human embryo, Stem cells, Social construction of the person, Biologization 